\title{
Nutritive Value and Preference of Guinea-Grass Ensiled with or without Additive by West African Dwarf (WAD) Goats
}

\author{
T. O. Abegunde*, S. O. Babalola, B. T. Adeoye, A. O. Usman, \& O. M. Akinfemi \\ Department of Animal Sciences, Obafemi Awolowo University, Ile-Ife, Osun State, 220282, Nigeria \\ ${ }^{*}$ Corresponding author: tayeabegunde2@yahoo.com \\ (Received 29-05-2020; Revised 14-09-2020; Accepted 14-10-2020)
}

\begin{abstract}
A study was designed to investigate silage additives' effect on preference and nutritive value of five weeks re-growth guinea grass by West African dwarf (WAD) goats. The silages of five weeks regrowth guinea grass were made without additive (T1), with cassava peels additive (T2), and with fermented epiphytic juice of lactic acid bacteria in Panicum maximum (FEJPM) additive (T3). The effects of silage additives on preference, voluntary feed intake, growth, digestibility, and nitrogen utilization were assessed using 18 growing WAD goats (BW: $5.88 \pm 0.26 \mathrm{~kg}$ ) in a completely randomized design. Dry matter was significantly $(\mathrm{p}<0.05)$ higher in T2 silage $(40.70 \mathrm{~g} / 100 \mathrm{~g})$ than in T1 silage $(39.00)$ and T3 silage (34.60). Crude protein values were similar $(\mathrm{p}>0.05)$ in T1 and T3 silages (10.63 and 10.72 $\mathrm{g} / 100 \mathrm{~g} \mathrm{DM})$ that were significantly lower $(\mathrm{p}<0.05)$ than that in T2 silage $(12.54 \mathrm{~g} / 100 \mathrm{~g} \mathrm{DM})$. The silages of guinea grass had acceptable physical attributes in terms of color, odor, and texture, with $\mathrm{pH}$ values ranging from 3.87- 4.97. T1 and T3 silages were rejected, whereas T2 silage was accepted well by the experimental WAD goats. Average daily feed intake (ADFI) was significantly $(p<0.05)$ the highest in the WAD goats fed T2 silage ( $303.30 \mathrm{~g} /$ day), and the lowest $(\mathrm{p}<0.05)$ was found in WAD goats fed T1 silage (271.60 g/day). Similar to the ADFI, the highest average daily gain (ADG) was found in WAD goats fed T2 silage ( $37.25 \mathrm{~g} / \mathrm{day})$, and the lowest ADG $(\mathrm{p}<0.05)$ was found in WAD goats fed T1 silage $(24.50 \mathrm{~g} /$ day). Feed conversion ratio (FCR) of WAD goats fed T2 silage (8.15) was superior to those of WAD goats fed T1 silage (13.63) and T3 silage (9.66). Crude protein and dry matter digestibility values were higher $(\mathrm{p}<0.05)$ in WAD goat fed T2 silage $(68.24$ and $63.87 \%$, respectively) than in WAD goats fed T1 and T3 silages. Nitrogen intake and balance were significantly $(p<0.05)$ the highest in WAD goats fed T2 silage (12.41 and $8.68 \mathrm{~g} /$ day, respectively), and these variables were similar in WAD goats fed T1 and T3 silages. Nitrogen retention was not affected by the silage additives. It was concluded that cassava peels were better than FEJPM as a silage additive since it improved fermentative quality, acceptability, feed intake, and digestibility of guinea grass silage by WAD goats.
\end{abstract}

Keywords: cassava peels; fermentation quality; growth; guinea grass; west african dwarf goat

\section{INTRODUCTION}

The making of silage involves the use of silage additives particularly when tropical grasses containing low sugar levels are the major resource or component of the silage. Silage additives are included in forage or crop residues at ensiling. Silage additives may improve the ensilage, reduce the silage losses, reduce aerobic deterioration during feed out, improve the hygienic quality of the silage, limit secondary fermentation, improve aerobic stability, and increase the nutritive value of the silage. These improvements will increase animal production with a higher return that is greater than the cost of additive paid by the farmer (Yitbarek \& Tamir, 2014). In sub-Saharan Africa, additives such as molasses, cassava peels, sugar cane, maize, wheat offal, and corn offal are quite expensive and compete with other livestock and industrial processing units. The costs and availabilities of commercial silage additives such as mo- lasses and other materials listed above are limited, and waste materials can then be used as substitutes for silage production. Utilizations of waste materials depend on accessibility and their possible nutritive values for livestock (Odedire \& Abegunde, 2014). Cassava peel used to be the more available among the alternative additives with a considerable level of WSC that is high enough for adequate fermentation of quality silage in the tropics. Olorunnisomo \& Fayomi (2012) and Olorunnisomo \& Adesina (2014) report that cassava peels have a high potential to be used as a feed source to cut production costs and also to increase the percentage of dry matter (DM) content of silages. This potential may be related to the relatively high dry matter contents of cassava peels (Anya \& Ozung, 2018). Napasirth et al. (2015) reported that the dried by-products of the cassava processing show characteristics that can improve the final quality of the silage, owing to their high DM contents, which could cause an elevation of the silage DM and, as a 
result, would reduce the losses of nutritive value by effluent. Moreover, cassava peels are potential sources of high-density energy with highly fermentable carbohydrates in the rumen. However, its use has been waned recently due to the rising competition for its use as feed for ruminants and pigs (High-quality cassava peels) (Adesehinwa et al., 2016).

Epiphytic lactic acid bacteria (LAB) are important for spontaneous silage fermentation and are a relatively small collection of microorganisms, not more than one percent of the total microbiome in plants (Fabiszewska et al., 2019). Epiphytic LAB ensures the fermentation of ensiled material mainly by the amount and type of organic acids produced, at the same time influencing the stability of the obtained silage (Muck, 2013). The epiphytic LAB is usually collected from plants in a juice form. In Nigeria, Napier grass is restricted to waterlogged areas and river banks hence their utilization for small ruminants may be burdensome. However, guinea grass (Panicum maximum) is predominant in the southern part of Nigeria. It produces high yields of palatable fodder, but its nutritive value rapidly declines with age. Therefore, its conservation into silage at the most nutritive stage of growth is recommended. There is a paucity of information on the use of fermented epiphytic juice of lactic acid bacteria (FEJPM) from P. maximum as an additive in ensiling of 5 weeks re-growth $P$. maximum as a feed for WAD goats.

This study was designed to comparatively assess the silage quality, nutritive value, and preference of 5-weeks re-growth $P$. maximum grass ensiled without additive, with cassava peels additive, and with fermented epiphytic juice of lactic acid bacteria (FEJPM) additive from $P$. maximum by West African dwarf (WAD) goats.

\section{MATERIALS AND METHODS}

\section{Statement of Ethics}

The Authors confirm that animal studies have been approved by ethical committee of the Departmental Animal Research and Ethical Committee, Obafemi Awolowo University, Ile-Ife, Osun State, Nigeria with approval number ANS/ARC/002. The research complied with internationally acceptable standards on humane care and use of animals for scientific purpose.

\section{Experimental Location}

The study was carried out at the Sheep and Goat Unit of Obafemi Awolowo University (OAU) Teaching and Research Farm, Ile-Ife, Osun State, Nigeria. This facility lies between latitude $7^{\circ} 33^{\prime \prime} \mathrm{N}$ and longitude $4^{\circ}$ $33^{\prime \prime} \mathrm{E}$ in the tropical rainforest ecological zone of Nigeria with an altitude of about $244 \mathrm{~m}$ above sea level (Shittu \& Amusan, 2015). Chemical analysis of diets and fecal samples were done in the Poultry Meat Laboratory of the Faculty of Agriculture, OAU, Ile-Ife, Osun State, Nigeria.

\section{Experimental Materials}

Silage production. Panicum maximum grass was cut back and harvested after five weeks re-growth. They were wilted for a day and then chopped into lengths of about 2-3 cm using a grass chopper machine (Fabricated). Cassava peels were obtained from the garri (fermented cassava flakes) processing unit on the OAU T\&R farm. The fermented juice of epiphytic lactic acid bacteria from $P$. maximum was prepared following the method as described by Bureenok et al. (2012). In brief, about $200 \mathrm{~g}$ of fresh guinea grass was chopped and blended using a Qlink home blender with $1000 \mathrm{~mL}$ of sterilized distilled water and sieved with a double layer cheesecloth to extract juice from it. $2 \%$ edible glucose (spec: $\mathrm{pH}-4.5-$ 6.0; DM - 95.5\%; Density - 450-530 g/L) was added to $750 \mathrm{~mL}$ of the juice, bottled, capped, and allowed to ferment anaerobically for 2 days at room temperature $\left(23.0^{\circ} \mathrm{C}-24.0^{\circ} \mathrm{C}\right)$. The materials itemized above were used as additives in ensiling $P$. maximum as described: $\mathrm{T}_{1}$ was Panicum maximum grass ensiled without additive; $\mathrm{T}_{2}$ was Panicum maximum grass ensiled with $30 \%$ chopped cassava peels; and $\mathrm{T}_{3}$ was Panicum maximum grass mixed with fermented juice of epiphytic LAB from Panicum maximum grass (FEJPM).

The silage was incubated for 28 days before being fed to the WAD goats. Supplemental concentrate diet ( $40 \%$ of total diet) was offered to animals along with the silage diets during growth trials with the following gross composition: $45 \%$ wheat offal, $27 \%$ brewer dry grain, $26 \%$ palm kernel cake, $1 \%$ vitamin and mineral premix (Calcium-15.3\%, phosphorus-8.0\%, pottasium- $0.10 \%$, Magnesium- $0.75 \%$, Lysine- $0.7 \%$, methionine- $0.35 \%$, copper-2500 ppm, zinc-4000 ppm, vit A-300,000IU/LB, vit E-200IU/LB, selenium-50.0ppm) with $1 \%$ salt.

\section{Physico-Chemical Variables}

Physico-chemical variables were assessed by following the methods described by Olorunisomo (2011). Briefly, after 28 days, the small bags were opened, and the diets were characterized. The characteristics of interest were color, odor (smell), temperature, texture, and $\mathrm{pH}$. Subsamples were taken from different points and depths, pooled together, and the moisture content was determined by oven drying at $65^{\circ} \mathrm{C}$ to a constant weight. The samples were ground in a hammer-mill and characterized chemically. To measure $\mathrm{pH}, 100 \mathrm{~g}$ subsample was heated in a beaker containing $100 \mathrm{ml}$ distilled water at $60^{\circ} \mathrm{C}$ for $5 \mathrm{~min}$. The supernatant was decanted, cooled at room temperature, and the $\mathrm{pH}$ was measured. The temperature and $\mathrm{pH}$ of the silage were measured by using a $\mathrm{pH}$ meter installed with a thermometer (Extech $\mathrm{PH}$ 100, Exstik pH Waterproof meter). The color of the silage was assessed with a color chart, while the odor and texture of the silage mixtures were judged by a panel of six persons (Falola et al., 2013).

\section{Preference Trials}

Preference trials were conducted by using fifteen (15) WAD goats $(5.88 \pm 0.26 \mathrm{~kg})$ in a cafeteria model 
to evaluate the acceptability of ensiled mixtures. The experimental animals were housed together in the opensided free stall pen constructed with hardwood and concrete floors. The experimental animals were preconditioned to the silage diets for 4 days before the start of the experiment. This acclimation period is provided to allow the experimental animals to get accustomed to the diets and to ascertain the level of intake. The experimental animals were offered two troughs for each diet, with each containing $2 \mathrm{~kg}$ of silage for a period of 5 hours daily for seven days. The position of the feed trough was changed daily to remove bias by the animals in recognizing part of the pen for a particular diet. Freshwater was offered ad-libitum. After five hours, the remnants were deducted from the amount of offered feed to arrive at free choice intake. The coefficient of preference (CoP) was calculated by dividing the individual silage intake by the average intake of all silage diets (Ososanya \& Olorunnisomo, 2015). Preference of a particular silage diet was rated higher when CoP is equal to or higher than one (1), while ranking was done based on the percentage of preference.

$\mathrm{COP}=$ Intake of individual feed / Mean intake of all the feed offered

\section{Growth Performance, Feed Digestibility, and Nitrogen Utilization}

The study of growth performance lasted for 8 weeks with 15 growing WAD goats with 5 goats per treatment, so each treatment was replicated 5 times. At the commencement of the study, each WAD goat was weighed using a hanging scale and sack and was subsequently weighed weekly throughout the study. Feed refusal, feed intake, and weight gain were variables measured during the study. At the termination of the growth trial, three animals randomly picked per treatment were transferred into metabolism cages fitted with facilities for separate collection of feces and urine. Total feces voided per animal were weighed, and aliquot samples were taken per day and dried in the oven at $70^{\circ} \mathrm{C}$ for 24 hours for dry matter determination. Daily aliquot samples of feces for each animal were pooled, mixed thoroughly, milled, and a sub-sample was taken for chemical analysis. Urine volume collected from each animal was measured, and daily $10 \%$ aliquot was taken, and volatilization of nitrogen from the sample was prevented by introducing $0.1 \mathrm{~N}$ of $\mathrm{HCl}$ into the sample and then stored in a deep freezer and later analyzed for nitrogen content.

\section{Determination of Nutrient Composition}

For the purpose of laboratory analysis, smaller packs of each diet prepared in triplicates were opened at the end of 28 days, and the samples were oven-dried at $65^{\circ} \mathrm{C}$ until a constant weight was obtained for dry matter determination, after which they were milled. Ether extract, crude fiber, crude protein $(\mathrm{CP})$, ash, and nitrogen free extract (NFE) of the diets were analyzed as described by the standard procedures of AOAC (2012).
The ether extract was estimated by the extraction method. Two (2) grams of the sample were weighed on the dry filter paper/thimble and inserted into a Soxhlet's apparatus (Gallenkamp model no EV 100). Petroleum ether $(150 \mathrm{mls})$ was poured into the flask. The soxhlet's apparatus was then connected to the flask containing the petroleum ether and to a condenser clamped to a retort stand. The flask was then heated until the content started boiling. The fat was separated from the petroleum ether by distillation. After distillation, the flask containing the fat was dried, cooled in desiccators, and weighed.

Percentage EE $=\mathrm{Wt}$. of thimble + sample before extraction - wt. of thimble + sample after extraction x 100/2 g (initial wt. of sample).

The crude fibre was determined by weighing $2 \mathrm{~g}$ of sample into a $250 \mathrm{~mL}$ conical flask and TCA reagent $(100 \mathrm{~mL})$ was added to the sample and digested for 40 minutes by reflux. It was then filtered to obtain the residue. The residue was washed 6 times using distilled boiling water and finally with $10 \mathrm{mLs}$ of acetone. It was then dried in an oven at $105^{\circ} \mathrm{C}$ overnight. The residue was scraped into a crucible and weighed. This was then ashed in a muffle furnace at $550^{\circ} \mathrm{C}$ for 2 hours. The ash sample was removed and cooled in desiccators, after which the ash was weighed together with the crucible. Weight of crucible + residue $=W 2$; Weight of crucible + ash $=$ W3; Weight of sample $=$ W1; Weight of crucible + residue - weight of crucible+ash $x 100$ Initial sample weight (2 g).

Crude protein $(\mathrm{CP})$ was determined using micro Kjeldahl method consisting of digestion, distillation and titration. The digestion was done by weighing $2 \mathrm{~g}$ of sample into $500 \mathrm{~mL}$ Kjeldahl digestion flask and adding $7 \mathrm{~g}$ potassium sulfate to the mixture. After that $0.5 \mathrm{~g}$ of crystal copper sulfate (catalyst) and $15 \mathrm{~mL}$ concentrated $\mathrm{H}_{2} \mathrm{SO}_{4}$ were also added. The flask was dampened in an inclined position in a woody cupboard that has an in-built extractor to convey the toxic fumes away from the environment. The mixture was then heated to boil until a clear light blue or green solution was observed. The solution was allowed to cool and transferred into a $100 \mathrm{ml}$ standard or volumetric flask. This was then diluted with distilled water and filled up to make the solution ready for distillation. The distillation procedure involved putting $25 \mathrm{~mL}$ of the digest into the micro Kjeldahl and adding $25 \mathrm{~mL}$ of $40 \%$ sodium hydroxide. A blue coloration was formed, which turned dark brown as distillation continued. The released ammonia gas was condensed and collected into a receiver containing $10 \mathrm{ml}$ of boric acid. The pinkish boric acid color changed into a green color because nitrogen in form of ammonia was absorbed by boric acid solution. The ammonia was then distilled till the volume of boric acid became $50 \mathrm{~mL}$. After distillation, the green-colored ammonium borate was then back titrated with $0.01 \mathrm{~mL} \mathrm{HCl}$ acid until the end point of the pink colour was obtained.

The ash content was determined by measuring two grams ( $2 \mathrm{~g})$ of the sample into a silica crucible. The sample was burnt continuously over a burner until smoke ceases. The crucible was placed in a muffle furnace and 
heated to $600^{\circ} \mathrm{C}$ for $2 \mathrm{hrs}$. At this temperature, all organic matter was burnt leaving behind minerals. The crucible was removed from the furnace carefully and cooled in desiccators at room temperature, and weighed again.

Percentage Ash = W2 - W0/W1 - W0 x 100

Where $\mathrm{W} 0$ = weight of empty crucible, W2 = crucible + sample, $\mathrm{W} 1$ = crucible + sample after burning.

Nitrogen free extracts (NFE) was determined based on the difference using the formula below:

$\mathrm{NFE}=100-[\%$ crude protein $+\%$ Ether extract $+\%$ crude fibre $+\%$ ash]

\section{Determination of Anti-Nutrients and Organic Acid Contents of Silages}

Tannin, phytates and oxalate were determined by following the procedures as previously described by Auwal et al. (2019), while alkaloid determination was according to the methods described by Ezeonu \& Ejikeme (2016). Silage samples were air-dried, pulverized using a porcelain mortar, and the powdered samples were kept in a plastic container till analysis. Determination of tannin is described briefly, previously dried, pulverized silage samples $(0.1 \mathrm{~g})$ were placed inside $100 \mathrm{~cm}^{3}$ conical flask and $350 \mathrm{~cm}^{3}$ of distilled water was added. The flask was gently heated to boiling for 1 hour, filtered while hot and the filtrate collected in a $50 \mathrm{~cm}^{3}$ volumetric flask. The residue was washed several times, while distilled water was used to top the combined solution volume. To 1,2 , and $3 \mathrm{~cm}^{3}$ of the standard tannic acid and $10 \mathrm{~cm}^{3}$ of the sample solution in a $50 \mathrm{~cm}^{3}$ volumetric flasks, 2.5 $\mathrm{cm}^{3}$ Folin-Denis reagent and $10 \mathrm{~cm}^{3}$ of $\mathrm{Na}_{2} \mathrm{CO}_{3}$ solutions has been added and distilled water was used to top the volume of the solution. Optical density was read at 760 $\mathrm{nm}$ after the flask was allowed to stand for 20 minutes.

Phytate levels were quantified by soaking previously dried, pulverized silage samples $(4 \mathrm{~g})$ in 100 $\mathrm{cm}^{3}$ of $2 \% \mathrm{HCl}(\mathrm{w} / \mathrm{v})$ and allowed to stand for over 3 hours before filtration. As much as $25 \mathrm{~cm}^{3}$ of the filtrate was taken and placed in a conical flask, $5 \mathrm{~cm}^{3}$ of $0.3 \%$ $\mathrm{NH}_{4} \mathrm{SCN}(\mathrm{aq})$ and $53.5 \mathrm{~cm}^{3}$ of distilled water were mixed together to act as an indicator and titrated against standard $\mathrm{FeCl} 3$ (aq) having $0.00195 \mathrm{~g} \mathrm{Fe} / \mathrm{cm}^{3}$ and observed the formation of brown-yellow color which may persist for 5 minutes. Blank was treated in a similar manner. The equivalent was obtained from this; the phytate content in $\mathrm{mg} / 100 \mathrm{~g}$ was calculated from equivalent= titre value $x 1.95$

Phytic acid - titre value x $1.95 \times 1.19 \times 3.355 \mathrm{mg} /$ phytic acid

$\%$ phytic acid $=($ titre value $\times 8.24 / 1000) \times 100 /$ weight of sample

Oxalate content was measured by putting $1 \mathrm{~g}$ of pulverized silage powder into $100 \mathrm{~cm}^{3}$ flask into which $75 \mathrm{~cm}^{3}$ of $3 \mathrm{MnH}_{2} \mathrm{SO}_{4}$ was also measured and stirred for about 1 hour. The filtration of the solution was carried out using a Whatman No 1 filter paper. As much as 25 $\mathrm{cm}_{3}$ of the filtrate was measured and titrated over $0.05 \mathrm{M}$ potassium permanganate $\left(\mathrm{KMnO}_{4}\right)$ solution till a palepink color is observed, and $1 \mathrm{~mL}$ of $0.05 \mathrm{~m} \mathrm{KMnO}_{4}$ was used to calculate the oxalate content.
For the determination of alkaloids, exactly $200 \mathrm{~cm}^{3}$ of $10 \%$ acetic acid in ethanol was added to $2.50 \mathrm{~g}$ of each of the previously pulverized silage samples in a $250 \mathrm{~cm}^{3}$ beaker and allowed to stand for 4 hours. The extract was concentrated on a water bath to one-quarter of the original volume, followed by the addition of 15 drops of concentrated ammonium hydroxide dropwise to the extract until the precipitation was complete immediately after filtration. After 3 hours of mixture sedimentation, the supernatant was discarded and the precipitates were washed with $20 \mathrm{~cm}^{3}$ of $0.1 \mathrm{M}$ of ammonium hydroxide and then filtered using Gem filter paper $(12.5 \mathrm{~cm})$. Using electronic weighing balance, the residue was dried in an oven and the percentage of the alkaloid is expressed mathematically as:

$\%$ Alkaloid $=($ weight of alkaloid/weight of sample $) \times 100$

Saponin values were determined according to the method described by Ani et al. (2019). Five grams of sample was weighed and extracted with hexane in a $50.0 \mathrm{~mL}$ vial. The extract was filtered and the filtrate was then injected into a Buck scientific (USA) BLC10/11 High Performance Liquid Chromatography (HPLC) system fitted with a fluorescence detector (excitation at $295 \mathrm{~nm}$ and emission at $325 \mathrm{~nm}$ ) and an analytical silica column (25 cm x $4.6 \mathrm{~mm}$ ID, stainless steel, $5 \mu \mathrm{m}$ ). The mobile phase used was hexane: tetrahydrofuran: Iso-propanol $(1000: 60: 4 \mathrm{v} / \mathrm{v} / \mathrm{v})$ at a flow rate of $1.0 \mathrm{~mL} / \mathrm{min}$. Standards of the antinutrient was prepared. The prepared standards were treated and analyzed in the same manner as the samples using the same method. The area of each peak from both samples and standards chromatograph were calculated and recorded. The concentration of the antinutrient was calculated using the following formula: [Conc. of Antinutrient] $=$ [SAMPLE $x$ [STD] $(\mathrm{ppm}) \times \mathrm{V}$ $\operatorname{HEX}(\mathrm{ml})] /[S T D \times \mathrm{Wt}$ SAMPLE $(\mathrm{g})]$

Where [Conc. of antinutrient] was concentration of Antinutrient in ppm; [STD] was concentration of standard; SAMPLE was peak area of sample; STD waspeak area of standard; V HEX was volume of hexane; and Wt SAMPLE was weight of sample.

Volatile fatty acid (VFA) compositions of the silage samples were determined using the methods of Daniel \& Resende (2012). VFA concentrations were determined in supernatant obtained after centrifugation at $8,855 \mathrm{~g}$ for 15 minutes at room temperature. Samples were analyzed for VFA by Gas Liquid Chromatography (G3175A, Agilent Tech, 5975 series with flame ionization detector,, USA) using a capillary column with nitroterephthalic acid-modified phase, chemically bonded polyethylene glycol, $25 \mathrm{~m} \times 0.25 \mathrm{~mm}$ I.D. and $0.2 \mathrm{~m}$ of film thickness (CP-Wax 58 (FFAP) CB, Varian Analytical Instruments, California, USA), and N2 as carrier gas. The oven temperature was set at $65^{\circ} \mathrm{C}$ for $30 \mathrm{~s}$, then increased to $125^{\circ} \mathrm{C}$, at a rate of $20^{\circ} \mathrm{C} /$ minute, and then increased again to $170^{\circ} \mathrm{C}$, at a rate of $50^{\circ} \mathrm{C} /$ minute. Total time of analysis was 4.9 minutes.

The colorimetric method (Ventura-Canseco et al. 2012) was used to determine the lactic acid content of silage diets. Briefly, $1 \mathrm{~mL}$ of standard solution was mixed in a vortex mixer with $6 \mathrm{~mL}$ of concentrated $\mathrm{H}_{2} \mathrm{SO}_{4}$ in $10 \mathrm{~mL}$ borosilicate tubes The mixed solutions were in- 
cubated in a water bath at $95-100^{\circ} \mathrm{C}$ for 10 minutes. The tubes were then cooled to room temperature, and 100 $\mu \mathrm{L}$ of $\mathrm{CuSO}_{4}$ and $200 \mu \mathrm{L}$ of para-phenyl phenol reagents were added and mixed on a vortex mixer. The tubes were kept at room temperature $\left(23-24^{\circ} \mathrm{C}\right)$ for 30 minutes, and the absorbances of the mixtures were measured at $570 \mathrm{~nm}$. All analyses were done three times.

\section{Statistical Analysis}

Data collected were subjected to one-way analysis of variance (ANOVA) using the procedure of Statistical Analysis System (SAS, 2012). Where significant, treatment means were separated using the Duncan Multiple Range Test of the same package.

\section{RESULTS}

Nutrient compositions of concentrate and silage diets are shown in Table 1. Dry matter (DM) contents of silages were significantly affected by the treatment of silage additives. T2 silage with a DM content of $40.70 \%$ was significantly $(p<0.05)$ higher than the others. T3 silage recorded the lowest $(\mathrm{p}<0.05)$ DM value of $34.60 \%$. The crude protein content of $12.54 \%$ for $\mathrm{T} 2$ silage was significantly $(\mathrm{p}<0.05)$ higher than T1 $(10.63 \%)$ and T3 $(10.72 \%)$ silages. Crude fiber content was higher in T3 silage than in $\mathrm{T} 2$ silage $(\mathrm{p}<0.05)$. However, $\mathrm{T} 1$ silage had similar CF content to T3 and T2 silages. Ash contents of T3 and T2 silages were higher $(p<0.05)$ than that of
T1 silage. However, T3 and T2 silages had similar ash contents. The highest lignin content was found in T2 silage. However, the lignin contents of T1 and T3 silages were similar. In contrast, EE, NFE, ADF, and NDF of the silages produced were not affected by the additives used for ensiling.

Table 2 shows the levels of secondary compounds in the silages. The treatments were significantly $(p<0.05)$ affected the levels of secondary metabolites (tannin, phytates, saponin, oxalate, and alkaloids) in the diets. The highest values for all the antinutrients assessed were observed in $\mathrm{T} 1$ silage, followed by $\mathrm{T} 2$ silage, and the lowest values were observed in T3 silage.

The VFA and lactic acid levels in the silage treatment are showed in Table 3. Butyric, propionic, and acetic acids were significantly $(\mathrm{p}<0.05)$ higher in T2 than the other treatments, while $P$. maximum silages without additives (T1) had the lowest values for VFA. The value obtained for both propionic and acetic acids were significant $(\mathrm{p}<0.05)$, ranging from $2.42 \%$ (T1) to $4.62 \%$ (T2) and $4.54 \%$ (T1) to $8.66 \%$ (T2), respectively, for propionic and acetic acids. T2 silage also had the highest butyric acid $(3.49 \%)$, followed by T3 silage $(2.30 \%)$, and the lowest was T1 silage $(1.88 \%)$. Lactic acid contents of silages were significantly affected by the additive treatment. Lactic acid contents of T2 and T3 silages were similar and significantly higher $(\mathrm{p}<0.05)$ than that of $\mathrm{T} 1$ silage.

The physicochemical properties of $P$. maximum ensiled with FEJPM and cassava peels is shown in Table 4. The $\mathrm{pH}$ values ranged from 3.87 to 4.97 . Differences

Table 1. Nutrient composition (\%) of concentrate and silage diets

\begin{tabular}{|c|c|c|c|c|c|c|}
\hline \multirow{2}{*}{ Variables } & \multicolumn{3}{|c|}{ Silages } & \multirow{2}{*}{ SEM } & \multirow{2}{*}{$\mathrm{P}$} & \multirow{2}{*}{ Concentrate } \\
\hline & T1 & $\mathrm{T} 2$ & T3 & & & \\
\hline Dry matter & $39.00^{\mathrm{b}}$ & $40.70^{\mathrm{a}}$ & $34.60^{c}$ & 0.14 & $<0.0001$ & 88.95 \\
\hline Crude protein & $10.63^{b}$ & $12.54^{\mathrm{a}}$ & $10.72^{\mathrm{b}}$ & 3.32 & 0.0008 & 41.34 \\
\hline Crude fiber & $13.55^{\mathrm{ab}}$ & $11.40^{\mathrm{b}}$ & $14.16^{\mathrm{a}}$ & 0.79 & 0.0009 & 6.98 \\
\hline Ether extract & 3.45 & 3.45 & 3.32 & 0.22 & $<0.0001$ & 7.62 \\
\hline Ash & $13.83^{b}$ & $15.13^{a}$ & $16.01^{\mathrm{a}}$ & 0.43 & $<0.0001$ & 5.79 \\
\hline NFE & 43.01 & 49.07 & 51.04 & 3.63 & 0.0064 & 27.22 \\
\hline Lignin & $5.92^{\mathrm{b}}$ & $9.40^{\mathrm{a}}$ & $5.93^{b}$ & 1.01 & 0.0230 & - \\
\hline $\mathrm{ADF}$ & 34.05 & 36.94 & 41.66 & 3.01 & 0.5971 & - \\
\hline NDF & 51.83 & 55.06 & 61.21 & 2.84 & 0.4454 & - \\
\hline
\end{tabular}

Note: T1= Ensiled $P$. maximum without additives; T2= $P$. maximum ensiled with $30 \%$ chopped cassava peels; T3= $P$. maximum ensiled with $750 \mathrm{~mL}$ fermented juice of epiphytic lactic acid bacteria from P. maximum (FEJPM); SEM= Standard error of means; NFE: Nitrogen Free Extract; NDF= Neutral Detergent Fiber; ADF= Acid Detergent Fiber. Means in the same row with different superscripts differ significantly $(\mathrm{p}<0.05)$.

Table 2. Secondary compounds in Guinea grass ensiled with FEJPM and cassava peels

\begin{tabular}{|c|c|c|c|c|c|}
\hline \multirow{2}{*}{ Variables } & \multicolumn{3}{|c|}{ Silages } & \multirow{2}{*}{ SEM } & \multirow{2}{*}{$\mathrm{P}$} \\
\hline & $\mathrm{T} 1$ & $\mathrm{~T} 2$ & T3 & & \\
\hline Tannin (mg/100g) & $134.72^{\mathrm{a}}$ & $126.30^{\mathrm{b}}$ & $106.28^{c}$ & 4.22 & $<0.0001$ \\
\hline Phytates (mg/100g) & $91.02^{\mathrm{a}}$ & $86.31^{b}$ & $82.87^{c}$ & 1.18 & $<0.0001$ \\
\hline Saponin (mg/100g) & $13.85^{\mathrm{a}}$ & $10.69^{b}$ & $9.00^{c}$ & 0.71 & $<0.0001$ \\
\hline Oxalates (mg/100g) & $7.67^{\mathrm{a}}$ & $6.21^{\mathrm{b}}$ & $4.71^{\mathrm{c}}$ & 0.43 & $<0.0001$ \\
\hline Alkaloid (mg/100g) & $4653.33^{a}$ & $3493.33^{\mathrm{b}}$ & $2953.33^{c}$ & 251.21 & $<0.0001$ \\
\hline
\end{tabular}

Note: T1= Ensiled $P$. maximum without additives; $\mathrm{T} 2=P$. maximum ensiled with $30 \%$ chopped cassava peels; $\mathrm{T} 3=P$. maximum ensiled with 750 mL fermented juice of epiphytic lactic acid bacteria from P. maximum (FEJPM); SEM= Standard error of means. Means in the same row with different superscripts differ significantly $(\mathrm{p}<0.05)$. 
Table 3. Volatile fatty acid and lactic acid contents of guinea grass ensiled with FEJPM and cassava peels of the silage treatments

\begin{tabular}{lcccccc}
\hline \multirow{2}{*}{ Variables } & \multicolumn{3}{c}{ Silages } & SEM & P \\
\cline { 2 - 4 } & T1 & T2 & T3 & & 0.31 & 0.0007 \\
Butyric \% & $1.88^{\mathrm{c}}$ & $3.49^{\mathrm{a}}$ & $2.30^{\mathrm{b}}$ & & 0.31 & 0.0003 \\
Propionic \% & $2.42^{\mathrm{c}}$ & $4.62^{\mathrm{a}}$ & $3.01^{\mathrm{b}}$ & & 0.79 & $<0.0001$ \\
Acetic \% & $4.54^{\mathrm{c}}$ & $8.66^{\mathrm{a}}$ & $5.37^{\mathrm{b}}$ & & 0.79 & 0.15 \\
Lactic acid \% & $3.90^{\mathrm{b}}$ & $4.80^{\mathrm{a}}$ & $4.60^{\mathrm{a}}$ & & 0.15 \\
\hline
\end{tabular}

Note: $\mathrm{T} 1=$ Ensiled $P$. maximum without additives; $\mathrm{T} 2=P$. maximum ensiled with $30 \%$ chopped cassava peels; $\mathrm{T} 3=P$. maximum ensiled with 750 mL fermented juice of epiphytic lactic acid bacteria from $P$. maximum (FEJPM); SEM= Standard error of means. Means in the same row with different superscripts differ significantly $(\mathrm{p}<0.05)$.

were observed in the odor of the diets, with T2 silage and T3 silage having a pleasant fruity smell while T1 (without additive) had a slightly choking smell. The appearance of the silages ranged from green to brownish-green.

Table 5 shows the acceptability of the experimental silage diets by WAD goats. The coefficient of preference (CoP) values obtained for T1 (0.972) and T3 (0.973) were both below unity. Therefore, these diets were rejected. T2 silage (1.054) was observed to be above unity, and therefore it was preferred by goats.

The growth performance of WAD goats fed guinea grass ensiled with FEJPM and cassava peels are as shown in Table 6. Average daily feed intakes (ADFI) were significantly $(p<0.05)$ affected by silage diets. The highest ADFI was found in WAD goats fed silage with cassava peel (T2), followed by FEJPM silage (T3), and the lowest was found in the diet without silage additive (T1). The values of ADFI for goats ranged from 271.60$303.30 \mathrm{~g} /$ day. The total weight gain and average daily gain $(A D G)$ were significantly $(p<0.05)$ affected by the silage diets with the significantly highest ADG $(p<0.05)$ was found in WAD goats fed the T2 silage, followed by those fed the T3 silage, and the lowest was found in those fed the T1 silage. The feed conversion ratio (FCR) was significantly $(\mathrm{p}<0.05)$ lower for WAD goats fed T2 silage (8.15) than the values obtained for those fed T1 silage and T3 silage (13.63 and 9.66, respectively).

Table 7 shows the apparent digestibility (\%) of guinea grass ensiled with fermented $P$. maximum juice

Table 4. Physico-chemical variables of 5-weeks re-growth $P$. maximum ensiled with FEJPM and cassava peels

\begin{tabular}{|c|c|c|c|}
\hline \multirow{2}{*}{ Variables } & \multicolumn{3}{|c|}{ Silages } \\
\hline & $\mathrm{T} 1$ & $\mathrm{~T} 2$ & T3 \\
\hline Temperature $\left({ }^{\circ} \mathrm{C}\right)$ & 27.50 & 27.22 & 28.61 \\
\hline $\mathrm{pH}$ & 4.97 & 4.41 & 3.87 \\
\hline Odor & $\begin{array}{l}\text { Unpleasant, } \\
\text { choking }\end{array}$ & $\begin{array}{l}\text { Pleasant, } \\
\text { Fruity }\end{array}$ & $\begin{array}{l}\text { Pleasant, } \\
\text { Fruity }\end{array}$ \\
\hline Appearance & Olive green & $\begin{array}{l}\text { Brownish- } \\
\text { green }\end{array}$ & Green \\
\hline Texture & Moist, Firm & Firm & $\begin{array}{l}\text { Quite moist, } \\
\text { Firm }\end{array}$ \\
\hline
\end{tabular}

Note: $\mathrm{T} 1=$ Ensiled $P$. maximum without additives; $\mathrm{T} 2=P$. maximum ensiled with $30 \%$ chopped cassava peels; $\mathrm{T} 3=P$. maximum ensiled with $750 \mathrm{~mL}$ fermented juice of epiphytic lactic acid bacteria from P. maximum (FEJPM); $\mathrm{SEM}=$ Standard error of means. and cassava peels. Dry matter (DM) digestibility was significantly $(\mathrm{p}<0.05)$ affected by the treatments. The highest value for digestibility of DM has been observed in WAD goats fed T2 silage (68.24), followed by WAD goat fed T1 silage (50.05) and T3 silage (40.34). The highest crude protein digestibility was found in WAD goat fed T2 silage (63.87) followed by those fed T3 silage (49.70), and the lowest was found in those fed T1 silage (36.21). The digestibility of crude fiber and NDF were not affected by additives used for ensiling. The digestibility of ADF in WAD fed T2 silage (89.67) was higher $(p<0.05)$ than in those fed T1 silage (79.98). However, the digestibility of ADF in WAD fed T3 silage (83.58) was similar to those fed T2 and T1 silages.

Nitrogen utilization of WAD goats fed $P$. maximum grass ensiled with FEJPM and cassava peels are as shown in Table 8. Intake of nitrogen (g/day) was significantly $(\mathrm{p}<0.05)$ higher in WAD goats fed T2 silage than in both goats fed T1 and T3 silages, which were similar. These values ranged between 7.19 (T1) to 12.4 (T2). Fecal nitrogen excretion values ranged from 1.22 (T2) to 0.13 (T1). The highest nitrogen fecal excretion was found in WAD goats fed T2 silage $(\mathrm{p}<0.05)$, and the nitrogen fecal excretions in goat fed T3, and T1 silages were similar. Nitrogen excretion in urine and total nitrogen excretions, as well as nitrogen retention, were not affected by the silage used in the diet. All the diets in this study had positive nitrogen balances, and the highest nitrogen balance was found in goats fed T2 silage and goats fed T1 silage and T3 silage had similar nitrogen balances.

Table 5. Acceptability of 5-weeks re-growth P. maximum grass ensiled with FEJPM and cassava peels by WAD goats

\begin{tabular}{cccc}
\hline Diets & $\begin{array}{c}\text { Mean dry matter in- } \\
\text { take (MDMI) }(\mathrm{kgDM})\end{array}$ & CoP & Rank/ RPI \\
\hline T1 & 0.43 & 0.972 & 3 \\
T2 & 0.45 & 1.054 & 1 \\
T3 & 0.41 & 0.973 & 2 \\
\hline
\end{tabular}

Note: $\mathrm{MDMI}=$ Mean Dry Matter Intake; $\mathrm{CoP}=$ Coefficient of preference; RPI=Relative Preference; T1= Ensiled P. maximum without additives; $\mathrm{T} 2=P$. maximum ensiled with $30 \%$ chopped cassava peels; T3= P. maximum ensiled with $750 \mathrm{~mL}$ fermented juice of epiphytic lactic acid bacteria from $P$. maximum (FEJPM); SEM= Standard error of means. 
Table 6. Growth performance of WAD goats fed guinea grass ensiled with FEJPM and cassava peels

\begin{tabular}{lccccc}
\hline \multirow{2}{*}{ Variables } & \multicolumn{3}{c}{ Silages } & SEM & P \\
\cline { 2 - 3 } ADFI (g/day) & T1 & T2 & T3 & & \\
Concentrate & $133.30^{\mathrm{a}}$ & $125.00^{\mathrm{b}}$ & $125.00^{\mathrm{b}}$ & 0.55 & $<0.0001$ \\
Silage & $138.30^{\mathrm{c}}$ & $178.30^{\mathrm{a}}$ & $159.70^{\mathrm{b}}$ & 1.15 & $<0.0001$ \\
Total ADFI (g/day) & $271.60^{\mathrm{c}}$ & $303.30^{\mathrm{a}}$ & $284.70^{\mathrm{b}}$ & 1.64 & $<0.0001$ \\
AILW (Kg) & 4.68 & 4.70 & 4.68 & 0.07 & 0.9790 \\
AFLW (Kg) & 5.10 & 5.33 & 5.20 & 0.13 & 0.4954 \\
TWG (Kg) & $0.42^{\mathrm{c}}$ & $0.63^{\mathrm{a}}$ & $0.52^{\mathrm{b}}$ & 0.07 & 0.001 \\
ADG (g/day) & $24.50^{\mathrm{c}}$ & $37.25^{\mathrm{a}}$ & $30.39^{\mathrm{b}}$ & & 1.49 \\
FCR & $13.63^{\mathrm{a}}$ & $8.15^{\mathrm{c}}$ & $9.66^{\mathrm{b}}$ & 0.79 & 0.001 \\
\hline
\end{tabular}

Note: $\mathrm{T} 1=$ Ensiled $P$. maximum without additives; $\mathrm{T} 2=P$. maximum ensiled with $30 \%$ chopped cassava peels; $\mathrm{T} 3=P$. maximum ensiled with $750 \mathrm{~mL}$ fermented juice of epiphytic lactic acid bacteria from P. maximum (FEJPM); SEM= Standard error of means; ADFI- Average daily feed intake; AILW= Average initial live weight; AFLW= Average final live weight; TWG= Total weight gain; ADG= Average daily gain; FCR= Feed conversion rasio. Means in the same row with different superscripts differ significantly $(\mathrm{p}<0.05)$.

Table 7. Apparent nutrient digestibility (\%) of Guinea grass ensiled with FEJPM and cassava peels by WAD goats

\begin{tabular}{|c|c|c|c|c|c|}
\hline \multirow{2}{*}{ Variables } & \multicolumn{3}{|c|}{ Silages } & \multirow{2}{*}{ SEM } & \multirow{2}{*}{$\mathrm{P}$} \\
\hline & $\mathrm{T} 1$ & $\mathrm{~T} 2$ & T3 & & \\
\hline Dry matter & $50.05^{b}$ & $68.24^{a}$ & $40.34^{b}$ & 1.03 & 0.12 \\
\hline Crude protein & $36.21^{b}$ & $63.87^{a}$ & $49.70^{c}$ & 5.62 & 0.0083 \\
\hline Crude fiber & 49.70 & 60.26 & 51.74 & 4.12 & 0.6115 \\
\hline NDF & 86.85 & 91.77 & 88.83 & 1.11 & 0.2019 \\
\hline $\mathrm{ADF}$ & $79.98^{\mathrm{b}}$ & $89.67^{a}$ & $83.58^{\mathrm{ab}}$ & 1.70 & 0.0294 \\
\hline
\end{tabular}

Note: T1= Ensiled $P$. maximum without additives; $\mathrm{T} 2=P$. maximum ensiled with $30 \%$ chopped cassava peels; $\mathrm{T} 3=P$. maximum ensiled with $750 \mathrm{~mL}$ fermented juice of epiphytic lactic acid bacteria from P. maximum (FEJPM); SEM= Standard error of means. Means in the same row with different superscripts differ significantly $(\mathrm{p}<0.05)$.

Table 8. Nitrogen utilization by WAD goats fed Panicum maximum ensiled with FEJPM and cassava peels

\begin{tabular}{|c|c|c|c|c|c|}
\hline \multirow{2}{*}{ Variables } & \multicolumn{3}{|c|}{ Silages } & \multirow{2}{*}{ SEM } & \multirow{2}{*}{$\mathrm{P}$} \\
\hline & $\mathrm{T} 1$ & $\mathrm{~T} 2$ & T3 & & \\
\hline Nitrogen intake (g/day) & $7.19^{\mathrm{b}}$ & $12.41^{\mathrm{a}}$ & $7.92^{\mathrm{b}}$ & 1.33 & 0.2449 \\
\hline \multicolumn{6}{|c|}{ Nitrogen excretion (g/day) } \\
\hline Fecal & $0.13^{\mathrm{b}}$ & $1.22^{\mathrm{a}}$ & $0.68^{\mathrm{b}}$ & 0.17 & 0.0014 \\
\hline Urine & 2.51 & 2.51 & 1.63 & 0.40 & 0.6522 \\
\hline Total & 2.64 & 3.73 & 2.31 & 0.57 & 0.6514 \\
\hline Nitrogen balance & $4.55^{\mathrm{b}}$ & $8.68^{\mathrm{a}}$ & $5.61^{\mathrm{b}}$ & 0.76 & 0.0112 \\
\hline Nitrogen retention (\%) & 63.28 & 69.94 & 70.83 & 5.14 & 0.2132 \\
\hline
\end{tabular}

Note: $\mathrm{T} 1=$ Ensiled $P$. maximum without additives; $\mathrm{T} 2=P$. maximum ensiled with $30 \%$ chopped cassava peels; $\mathrm{T} 3=P$. maximum ensiled with $750 \mathrm{~mL}$ fermented juice of epiphytic lactic acid bacteria from P. maximum (FEJPM); SEM= Standard error of means. Means in the same row with different superscripts differ significantly $(\mathrm{p}<0.05)$.

\section{DISCUSSION}

The differences observed in DM content of the diets are probably due to the different additives included in the diets. T2 silage, which included cassava peels, was observed to have the highest DM because of the high DM contents of cassava peels compared to the other additives used. The low DM value observed in the diet ensiled with FEJPM as additive could be as a result of the liquid form of additive added or as a result of better fermentation from the epiphytic LAB from $P$. maximum grass included as a silage additive. $\mathrm{CP}$ contents for all diets exceeded the minimum level of $8 \%$ necessary for the maintenance of goats (NRC, 2007). This is the minimum $\mathrm{CP}$ needed to provide the minimum ammonia levels required by rumen microorganisms to support the optimum rumen activity (Soliva et al., 2015). Crude protein $(\mathrm{CP})$ values reported for silage diets in this study were similar to the $\mathrm{CP}$ range of 8.05 to 11.30 $\mathrm{g} / 100 \mathrm{~g}$ reported by Abegunde et al. (2019) for dried banana leaves ensiled with cassava peels and urea as feed for WAD sheep and were also similar to the $\mathrm{CP}$ values of 23.63 and $31.46 \mathrm{~g} / \mathrm{kg}$ for elephant grass ensiled with $10 \%$ wheat bran and $20 \%$ wheat bran, respectively as reported by Silva et al. (2014).

Levels of antinutrients reported in this study are 
below the threshold levels permissible in ruminant animals (Umar et al., 2014). Critical factors in ruminant nutrition are tannins and saponins. Plant antinutrients (condensed tannins and saponins) are important ingredients in feed for ruminants, particularly for methane mitigation strategy owing to their natural origin as opposed to chemical additives (Wanapat et al., 2013). An array of studies has documented CT-protein complexation and precipitation (Hagerman, 2012). Evidence from experiments suggests that tannins bind to proteins, forming a tannin coating of the protein through a surface adsorption mechanism, and this can lead to precipitation of the tannin-protein complex (Dobreva et al., 2011). This undermines the importance of ensuring that the secondary metabolites, particularly tannin, is consistent with the threshold levels recommended for goats.

Higher values of propionic and acetic acids reported for T2 silage imply that this diet had the highest energy contents, which might have been due to cassava peels' addition as an additive. The preponderance of butyric acid in T2 silage also indicates that this diet is more prone to spoilage as preponderant butyric acid indicates ease of spoilage since the higher the butyric contents in silage, the shorter the shelf life. Higher butyric acid contents of silage diets have also been reported to have a depressing effect on DM (Silva de Oliveira et al., 2016).

Well-made silage usually retains the original color of the forage used and has a pleasant and fruity odor, which emanates from the good quality silage that was well preserved (Falola et al., 2013). The green color was close to the original color of $P$. maximum grass. The light green color is indicative of the improved fermentation (Olorunnisomo \& Adesina, 2014). Also, the brownish color observed in T2 silage was a result of the color of added cassava peels. Ogunbosoye et al. (2016) report that pleasant smells are indicative of good quality silage. All silages had firm textures with varying degrees of firmness. Temperatures of silages were all below $30^{\circ} \mathrm{C}$. Kung et al. (2018) report that temperatures below $30^{\circ} \mathrm{C}$ are indicative of complete fermentation.

The concentration of lactic acid and buffering capacity of the crop are two of many factors affecting the final $\mathrm{pH}$ of silage (Kung et al., 2018). T3 silage had the lowest $\mathrm{pH}$. This low $\mathrm{pH}$ is an indicative of the efficiency of the FEJPM as an additive that acts as an inoculant for LAB known to increase the lactic acid content of silage (Bureenok et al., 2012). The preponderance of lactic acid in the silage reduces the $\mathrm{pH}$, which helps to stabilize the fermentation of the silage through the inhibition of growth or outright killing of microbe intolerant to low $\mathrm{pH}$.

Coefficients of preference below unity for T1 silage and T3 silage implied that these diets were rejected by goats. T2 silage had a value above unity (1), and this silage was preferred by goats. The preference of this diet may have been as a result of the cassava peels added to the treatment as an additive, which improved the fermentation and conferred a pleasant aroma on the silage diet. This corroborates the results of Falola et al. (2013), who reported an increase in the intake and preference of diets of vetiver grass ensiled with cassava peels by WAD goats compared to those that were not ensiled with cassava peels.

The ADFI values of 271.60-303.30 g/day reported in this study are lower than values of $484.47-742.96 \mathrm{~g} /$ day reported by Eyoh et al. (2019) when they fed different forms of processed guinea grass to WAD bucks. The high ADFI reported for T2 silage diet compared to the others may be due to the higher DM content of the silage since this diet contained cassava peels as an additive. Idowu et al. (2013) also reported a similar effect when they fed graded levels of toasted Enterolobium cyclocarpum seeds to WAD sheep as a supplement to guinea grass and suggested that diet containing $10 \%$ E. cyclocarpum seeds may have given the best synchronized release of nitrogen and carbohydrate in the rumen required for microbial protein synthesis. The values of the ADG reported in this study agree with those reported (Rahman et al., 2014) for goats fed elephant grass and oil palm frond supplemented with soy waste. Better gain exhibited by animals fed silage diet with cassava peels as an additive is not out of place since it corroborates the findings of Ajayi \& Omotosho (2018), who reported that feeding Albizia lebbeck - cassava peels silage as a feed for West African dwarf sheep in the dry season increased body weight gain. The benefit from cassava peels may be attributed to its dense fermentable energy and also high digestibility (Heuzé et al., 2016). Wanapat \& Kang (2015) reported that cassava tubers contained high amounts of readily fermentable carbohydrates and could be utilized together with readily available non-protein nitrogen (NPN) sources such as urea in ruminant feeds, and this could enhance the growth of rumen bacteria. The values (13.63-9.66) reported for FCR are similar to those (11.53-9.22) reported by Ibhaze (2015) for WAD goats fed fermented maizecob-based diets and lower than those (13.75-15.83) reported by Ajayi et al. (2016) for WAD goats fed corncob and cassava peels ensiled with poultry dropping. The lower FCR values observed for animals fed diet 2 (T2 silage) in this study implies the superiority of that diet over the others.

Higher values for digestibility of DM in T2 silage may be attributed to the better fermentation of this diet as a result of the use of cassava peels as an additive. Cassava peels used as an additive in silage production are known to enhance nutrient digestibility, as is reported by Olorunnisomo (2011) for Red Sokoto goats fed Napier grass ensiled with cassava peels. Crude protein digestibility, which shows the extent to which microbial protein is made accessible to the animals daily (Kissada et al., 2010), was significantly higher in T2 silage than in the others. This observation corroborates the findings of Jiang et al. (2015), who reported that the nutrient digestibility of diets increased with the increasing crude protein content. Low CP digestibility observed in T1 silage is probably due to the absence of additives during ensiling or low protein levels in the grass ensiled. Olorunnisomo (2011) reported the better digestibility of DM and CP in Red Sokoto goats fed elephant grass, and cassava peels silage compared to silage diets without cassava peels. The use of 5 weeks re-growth grass for the silage probably contributed to the similarity in terms of the CF and NDF digestibility because the ad- 
ditives used did not contribute significantly to the bulk. Apparent digestibility results generally indicate that in ruminant nutrition, $\mathrm{CP}$ and CF are important in enhancing microbial activities in the rumen (Abegunde \& Akinsoyinu, 2010). This condition was achieved with the mixture of grass and cassava peels, which showed the improved digestibility of nutrients in this study.

Values observed for nitrogen utilization, nitrogen balance, and nitrogen retention are all related to the amounts of nitrogen ingested and digested (Akinwande et al., 2019). All diets used in this study had positive nitrogen balances, which indicated adequacy in the protein requirement for maintenance (Abegunde \& Akinropo, 2018). The values reported for nitrogen intake in this study are lower than those reported by Akinwande et al. (2019) for WAD ewes fed ensiled Alternanthera brasiliana (19.05-22.85 g/d) but were higher than those reported by Mako et al. (2012) for WAD goats fed guinea grass and varying levels of Acroceras zizanioides (AZ) (3.85 -6.95 g/d). The same trend observed in nitrogen intake was also seen in fecal nitrogen excretion $(\mathrm{g} / \mathrm{d})$. The higher values observed for fecal nitrogen excretion in T2 silage runs contrary to the findings of Idowu et al. (2013), who fed graded levels of Toasted Enterolobium cyclocarpum seeds as a supplement to guinea grass. However, results in this study agree with those reported by Akinwande et al. (2019), Abegunde \& Akinropo (2018), and Mako et al. (2012). Nitrogen balance was positive for all diets and therefore suggested that nitrogen absorbed was well tolerated and utilized by goats. Nitrogen retention values were lower in this study than those reported elsewhere (Asaolu et al., 2010; Idowu et al., 2013; Akinwande et al., 2019). This observation is attributable to the total nitrogen content of the silage diets fed to goats in this study. Furthermore, nitrogen retention is now well established to depend on the intake of nitrogen and the level of fermentable carbohydrates in the feed (Hamchara et al., 2018).

\section{CONCLUSION}

From this study, the use of cassava peels as an additive has shown excellent results. Fermented juice of epiphytic LAB from Panicum maximum grass (FEJPM) as an additive is promising. However, the acceptability of silages with FEJPM as an additive should include a fermentable carbohydrate ingredient to enhance its palatability and intake by animals.

\section{CONFLICT OF INTEREST}

We certify that there is no conflict of interest with any financial, personal, or other relationships with other people or organization related to the material discussed in the manuscript.

\section{REFERENCES}

Abegunde, T. O. \& A. O. Akinsoyinu. 2010. Replacement effects of Panicum maximum with Ficus polita on performance of West African dwarf goats. J. of Anim. Physiol. and Anim. Nutrn. 95:192-197. https://doi. org/10.1111/j.1439-0396.2010.01040.x

Abegunde, T.O. \& T. F. Akinropo. 2018. Performance and haematological parameters of West African Dwarf goats fed water hyacinth ensiled with breadfruit. Bull Anim. Health Prod. Afr. 66:727-740.

Abegunde, T.O., J. A. Odedire, C. O. Akande, R. T. Omoleke, \& M. A. Adebayo. 2019. Nutritive value and acceptability of dry banana leaves ensiled with cassava peels and urea by West African Dwarf sheep. Intl. J. Agric. Env. Res. 5:216-230.

Adesehinwa, A. O. K., A. Samireddypalle, A. A. Fatufe, E. Ajayi, B. Boladuro, \& I. Okike. 2016. High quality cassava peel fine mash as energy source for growing pigs: Effect on growth performance, cost of production and blood parameters. Livest. Res. Rural Dev. 28:207. http://www.lrrd.org/ lrrd28/11/ades28207.html. [12 May 2020]

Ajayi, F. T. \& S. O. Omotosho. 2018. Potentials of Albizia lebbeck-cassava peel silage as dry season feed for West African dwarf sheep. Pertanika J. Trop. Agric. Sci. 41: 1151-1167.

Ajayi, F. T., S. O. Omotoso, \& T. O. Dauda. 2016. Performance and Nutrient Digestibility of West African Dwarf Goats Fed Corncob-Poultry Dropping Silage. The Pacific J. Sci. Tech. 17: 278-287.

Akinwande, V. O., A. A. Mako, S. Bakare, L. Sikiru, \& B. Taiwo. 2019. Performance, apparent digestibility and nitrogen utilization by West African dwarf ewes fed ensiled Alternanthera brasiliana (L.) O kuntze based diets. Slovak J. Anim. Sci. 52:16-23.

Ani, E., B. Igbabul, J. Ikya, \& J. Amove. 2019. Nutritional values, antinutritional factors and molar ratio of minerals to anti nutrients of plant based yoghurt from Bambara nut, soyabean and Moringa oleifera seed milk. Research Journal of Food and Nutrition. 3:18-28.

Anya, M. I. \& P. O. Ozung. 2018. Performance and carcass characteristics of West African dwarf (WAD) goats fed cassava peel meal based diets supplemented with African yam bean concentrate. Int. J. Adv. Agric. Sci. Technol. 5:95-108.

AOAC. 2012. Official Methods of Analysis of AOAC International. $19^{\text {th }}$ ed. Assoc. Off. Anal. Chem., Arlington.

Asaolu, V.O., S. M. Odeyinka, O. O. Akinbamijo, \& F. G. Sodeinde. 2010. Effects of moringa and bamboo leaves on groundnut hay utilization by West African Dwarf goats. Livest. Res. Rural Dev. 22:12. http://www.lrrd.org/ lrrd22/1/asao22012.html. [23 May 23 2016]

Auwal, M. M., J. M. Yelwa, I. Abubakar, J. B. Umar, B., H. G. Anchau, \& F. B. Tanimu. 2019. The levels of antinutritional factors in: Moringa oleifera and Vernonia amygdalina leaves found in some part of Plateau State, Nigeria. Oriental Journal of Physical Sciences. 4:1-5. https://doi. org/10.13005/OJPS04.02.06

Bureenok, S., C. Yuangklang, K. Vasupen, J. T. Schonewille, \& Y. Kawamoto. 2012. The effects of additives in Napier grass silages on chemical composition, feed intake, nutrient digestibility and rumen fermentation. Asian-Australas. J. Anim. Sci. 25:1248-1254. https://doi.org/10.5713/ ajas.2012.12081

Daniel, J. \& J. Resende. 2012. Absorption and metabolism of volatile fatty acids by rumen and omasum. Ciência e Agrotecnologia. 36:93-99. https://doi.org/10.1590/ S1413-70542012000100012

Dobreva, M. A., R. A. Frazier, I. Mueller-Harvey, L. A. Clifton, A. Gea, \& R. J. Green. 2011. Binding of pentagalloyl glucose to two globular proteins occurs via multiple surface sites. Biomacromolecules. 12:710-715. https://doi. org $/ 10.1021 / \mathrm{bm} 101341 \mathrm{~s}$

Eyor, G. D., M. D. Udo, \& C. P. Edet. 2019. Growth performance and carcass characteristics of West African bucks fed different forms of processed Guinea grass (Panicum maximum). Curr Agri Res. 7:2. https://doi.org/10.12944/CARJ.7.2.13 
Ezeonu, C. S. \& C. M. Ejikeme. 2016. Qualitative and quantitative determination of phytochemical contents of indigenous Nigerian softwoods. New J. Sci. vol. 2016, Article ID 5601327, 9 pages. https://doi.org/10.1155/2016/5601327

Fabiszewska, A.U., K. J. Zielińska, \& B. Wróbel. 2019. Trends in designing microbial silage quality by biotechnological methods using lactic acid bacteria inoculants: A mini review. World J. Microbiol. Biotechnol. 35:76. https://doi. org/10.1007/s11274-019-2649-2

Falola, O. O., M. C. Alasa, \& O. J. Babayemi. 2013. Assessment of silage quality and forage acceptability of Vetiver grass (Chrysopogon zizanioides L. Roberty) ensiled with cassava peels by WAD goats. Pak. J. Nutr. 12:529-533. https://doi. org/10.3923/pjn.2013.529.533

Hagerman, A. E. 2012. Fifty Years of Polyphenol-Protein Pomplexes. In: Recent Advances in Polyphenol Research. Vol. 3. $3^{\text {rd }}$ ed. Cheynier, V.; Sarni-Manchado, P. and Quideau, eds. John Wiley \& Sons, Ltd., Oxford, UK. p.7197. https://doi.org/10.1002/9781118299753.ch3

Hamchara, P., P. Chanjula, A. Cherdthong. \& M. Wanapat. 2018. Digestibility, ruminal fermentation, and nitrogen balance with various feeding levels of oil palm fronds treated with Lentinus sajor-caju in goats. Asian-Australas. J. Anim. Sci. 31:1619-1626. https://doi.org/10.5713/ajas.17.0926

Heuzé V., G. Tran, H. Archimède, C. Régnier, D. Bastianelli, \& F. Lebas. 2016. Cassava peels, cassava pomace and other cassava by-products. Feedipedia, a programme by INRA, CIRAD, AFZ and FAO. http://www.feedipedia.org/ node $/ 526$

Ibhaze, G. A. 2015. Feeding quality of fermented maizecob based diets as feed for west african dwarf goats. Applied Tropical Agriculture. 20: 52-56.

Idowu, O. J., O. M. Arigbede, P. A. Dele, J. A. Olanite, O. O. Adelusi, V. O. A. Ojo, \& A. S. Sunmola. 2013. Nutrients intake, performance and nitrogen balance of West African Dwarf sheep fed graded levels of toasted Enterolobium cyclocarpum seeds as supplement to Panicum maximum. Pak. J. Biol. Sci. 16:1806-1810. https://doi.org/10.3923/ pjbs.2013.1806.1810

Jiang, Q., G. Li, T. Zhang, H. Zhang, X. Gao, X. Xing, J. Zhao, \& F. Yang. 2015. Effects of dietary protein level on nutrients digestibility and reproductive performance of female mink (Neovison vison) during gestation. Anim. Nutri. 1:6569. https://doi.org/10.1016/j.aninu.2015.05.002

Kissada, B., W. Metha, \& N. Chainarong. 2010. Replacement of soybean meal by yeast fermented-cassava chip protein (YEFECAP) in concentrate diets fed on rumen fermentation, microbial population and nutrient digestibility in ruminants. J. Anim. Veter. Adv. 9: 1727-1734. https://doi. org/10.3923/javaa.2010.1727.1734

Kung, L., R. D. Shaver, R. J. Grant \& R. J. Schmid. 2018. Silage Review: Interpretation of chemical, microbial and organoleptic components of silages. J. Dairy Sci. 101:4020-4033. https://doi.org/10.3168/jds.2017-13909

Mako, A. A., V. O. Akinwande, O. I. Abiola-Olagunju, O. J. Babayemi, \& A.O. Akinsoyinu. 2012. Variations in chemical nutrients and mineral concentrations of water hyacinth (Eichhornia crassipes Mart. Solms- Laubach). Niger. J. Anim. Prod. 39:199-205.

Muck, R. 2013. Recent advances in silage microbiology. Agric. Food Sci. 22:3-15. https://doi.org/10.23986/afsci.6718

Napasirth, V.; P. Napasirth, T. Sulinthone, K. Phommachanh \& Y. Cai. 2015. Microbial population, chemical composition and silage fermentation of cassava residues. Anim. Sci. J. 86:842-848. https://doi.org/10.1111/asj.12362

NRC (National Research Council). 2007. Nutrient requirements of small ruminants: Sheep, goats, cervids, and new world camelids. The National Academies Press, Washington, DC. https://doi.org/10.17226/11654
Odedire, J. A. \& T. O. Abegunde. 2014. Effect of graded levels of Saccharum officinarum as an additive to Panicum maximum (Jacq) silage. African J. Food Agric. Nutr. Dev. 14:1-12

Ogunbosoye, D. O., J. A. Odedire. \& A. Akinfemi. 2016. Silage Characteristics and voluntary intake of ensiled maize residue- browse plants mixtures fed red Sokoto goats as dry season feedstuffs in Kwara State, Nigeria. Intl. J. Innov. Res. In Tech. Sci. 4: 62-67.

Olorunnisomo O. A. \& A. Adesina. 2014. Silage characteristics, nutritive value and preference of Zebu cows for moringa leaf ensiled with different levels of cassava peel. Agricultural Journal. 8:295-2298.

Olorunnisomo, O. A. 2011. Silage characteristics and acceptability of elephant grass and cassava peel silage by ruminants in southwest Nigeria. In: Proceedings, 3rd International Conference on Sustainable Animal Agriculture for Developing Countries (SAADC 2011), Volume III, 26 - 29 July, 2011, Nakhon Ratchasima, Thailand. p. 201-206.

Olorunnisomo, O. A. \& O. H. Fayomi. 2012. Quality and preference of Zebu heifers for legume or elephant grass-silages with cassava peel. Livest. Res. Rural Dev. 24:168.

Ososanya, T. O. \& O.A. Olorunnisomo. 2015. Silage characteristics and preference of sheep for wet brewer's grain ensiled with maize cob. Livest. Res. Rural Dev. 27:12.

Rahman, M. M., R. B. Abdullah, W. Wan Khadijah, T. Nakagawa \& R. Ryo Akashi. 2014. Feed intake and growth performance of goats fed with Napier grass and oil palm frond supplemented with soya waste. J. Appl. Anim. Res. 43:256-260. https://doi.org/10.1080/09712119.2014.963095

SAS. 2012. Statistical Analytical Systems. SAS Version 9.2 user's guide. SAS Institute, Carry, NY.

Shittu, K. A. \& A. A. Amusan. 2015. Effects of different agricultural land use types on physical properties under rainforest agroecology. African J. Agric. Res. 10:1817-1822. https:// doi.org/10.5897/AJAR2014.9143

Silva de Oliveira, J., E. M. Santos, \& A. P. Maia dos Santos. 2016. Intake and Digestibility of Silages, Advances in Silage Production and Utilization, Thiago da Silva and Edson Mauro Santos. InTech. https://doi.org/10.5772/65280

Silva, J., J. Oliveira, N. Ariosvalo, E. Santos, T. Magalhães, A. Ramos \& H. Bezerra. 2014. Elephant grass ensiled with wheat bran compared with corn silage in diets for lactating goats. Revista Brasileira de Zootecnia. 43:618-626. https:// doi.org/10.1590/S1516-35982014001100008

Soliva, C. R., S. L. Amelchanka, \& M. Kreuzer. 2015. The requirements for rumen-degradable protein per unit of fermentable organic matter differ between fibrous feed sources. Front. Microbiol. 6:715. https://doi.org/10.3389/ fmicb.2015.00715

Umar, K. J, L. Abubakar, B. Alhassan, S. D. Yahaya, L. G. Hassan, N. A. Sani, \& M. U. Muhammad. 2014. Nutritional profile of Balanites aegyptiaca flower. Studia Universitatis "Vasile Goldis". Seria Stiintele Vietii. 24:169-173

Wanapat, M. \& S. Kang. 2015. Cassava chip (Manihot esculenta Crantz) as an energy source for ruminant feeding. Anim. Nutr. 1:266-270. https://doi.org/10.1016/j.aninu.2015.12.001

Wanapat, M., S. Kang, \& S. Polyorach. 2013. Development of feeding systems and strategies of supplementation to enhance rumen fermentation and ruminant production in the tropics. J. Anim. Sci. Biotech. 4:32. https://doi. org/10.1186/2049-1891-4-32

Ventura-Canseco, L. C., J. M. Nunez, M. Abud.Archila, M. A. Olivia-Llaven, L. Dendooven, \& F.A. GuitierrezMiceli. 2012. Sugarcane molasse and whey as additives in the silage of lemon grass (Cymbopogon citrates [DC.] Stapf) leaves. Chilean J. Agric. Res. 72:87-91. https://doi. org/10.4067/S0718-58392012000100014

Yitbarek, M. \& B. Tamir. 2014. Silage additives: Review. Open J. Appl. Sci. 4:258-274. https://doi.org/10.4236/ ojapps.2014.45026 